the following: $2.23 ; 2.25 ; 2.39$ and $2.46 \mathrm{~kg} / \mathrm{day}$, the first two treatments differing significantly from the two others.

The growth rates obtained were related to the feed intake. Accordingly, the feed conversion ratios were similar for the 4 treatments (from 2.97 to 3.04 ), the highest value being obtained with ad libitum feeding.

It was observed that in most cases, the daily feed intakes were lower with pellets. This difference was statistically significant according to the results of the 4 treatments.

Growth performances and feed conversion ratios were always improved with pellets and this was all the more marked as the restriction was severe.

No significant difference was noticed between groups with respect to cutting criteria. The loin /backfat ratio was in favour of carcasses from animals having been restricted after ad libitum feeding and evolved parallel to the intensity of feed restriction. This was also the case for average backfat thickness. For these two criteria, the results obtained with progressive feed restriction (treatment $\mathrm{r}$ ) were located between those obtained with the more liberal treatments.

Consequently, fattening length of pigs, total feed intake and conmercial grading of carcasses cannot be optimized simultaneously.

\title{
Utilization of different varieties of fodder wheat by growing finishing pigs
}

\author{
J. P. BOUARD et M. LEUILIET \\ Institut Technique des Cévéales et des Fourrages, \\ 8, avenue du Président-Wilson, 75116 Paris
}

Two experiments were carried out with the aim of defining more accurately the feeding value of diets based on new varieties of wheat unfitted for bread-making as compared with various varieties fitted for bread-making. In the first experiment the animals were fed ad libitum during the growing-finishing period and in the second one, they were restricted during the finishing period.

The results obtained with the variety " Maris-Huntsman" in the two experiments were similar to those recorded with the classical varieties. Accordingly, data available about wheat can also be applied to the former variety.

The variety " Clement" exhibited the same feed efficiency in females and castrated males as the other varieties. However, a slight lowering in the intake level was noticed in castrated males leading to growth rate reduction.

Further assays should be performed to confirm the feeding value of the variety "Clement".

\section{Reduction of the protein level in wheat based diets offered to growing-finishing pigs}

\author{
J. CASTAING (1) et M. LeULlLet ${ }^{(2)}$ \\ (1) Association générale des Producteut's de Maïs \\ $I$, place de Lestapis, 64000 Pau (Fvance) \\ $\left({ }^{2}\right)$ Institut Technique des Céréales et des Fourrages \\ 8, avenue du Président-Wilson. 75It6 Paris
}

\begin{abstract}
Six wheat based diets differing by the protein supply (quantitative or qualitative) and protein source (soya-bean meal alone or combined with lucerne meal) were compared in this study using growing-finishing pigs.

The best growth performances were obtained with the highest crude protein level (i $8 \%)$ and then regularly decreased with the levels of 16.5 and 15 per cent. The differences were
\end{abstract}

